Instructions for authors, subscriptions and further details:

\title{
http://rise.hipatiapress.com
}

\section{Not Without Their Hijab: Being a Muslim Female Student at A Mid-Southern University}

Suhair A Mrayan ${ }^{1}$, Amany I Saleh ${ }^{1}$

1) Arkansas State University, United States

Date of publication: October $25^{\text {th }}, 2016$

Edition period: October 2016-February 2017

To cite this article: Mrayan, S.A., Saleh, A.I. (2016). Not Without Their Hijab: Being a Muslim Female Student at A Mid-Southern University. International Journal of Sociology of Education, 5(3), 244-267. doi: 10.17583/rise.2016.2132

To link this article: http://dx.doi.org/10.17583/rise.2016.2132

\section{PLEASE SCROLL DOWN FOR ARTICLE}

The terms and conditions of use are related to the Open Journal System and to Creative Commons Attribution License (CC-BY) 


\section{Not Without Their Hijab: Being a Muslim Female Student at A Mid- Southern University}

Suhair A Mrayan

Arkansas State University
Amany I Saleh

Arkansas State University

(Received: 13 June 2016; Accepted: 18 September 2016; Published: 25 October 2016)

\section{Abstract}

Scholars might agree or disagree on the best definition of Islamophobia, but no one can deny Islamophobia is a very real and dangerous phenomenon in American society. This research examined veiled Muslim students' experiences and perceptions of a typical American university campus in the aftermath of the most recent terrorist attacks. The findings demonstrated that students perceived the campus community to be tolerant and welcoming. On the other hand, students reported off-campus incidents that speak of ignorance and intolerance of Muslim students. The study provides higher education institutions with insights on how to increase cultural awareness on-and-off campus to correct stereotypes and make Muslim students feel welcomed in their communities. The authors hope to create awareness among students and community members; thereby helping to debunk the stereotypes, and creating a safe and diverse campus for all students. Educators and college leaders can use this knowledge to combat stereotypes and biases; thus making campus a safer and more welcoming environment for all students.

Keywords: Islamophobia, American college campus, Muslim students 


\section{No Sin su Hiyab: Ser una estudiante Musulmana en una Universidad del Medio-Sur}

Suhair A Mrayan

Arkansas State University
Amany I Saleh

Arkansas State University

(Recibido: 13 Junio 2016; Aceptado: 18 Septiembre 2016; Publicado: 25 Octubre 2016)

\section{Resumen}

Los académicos se pueden poner de acuerdo o no en la mejor definición de la islamofobia, pero nadie puede negar que la islamofobia es un fenómeno muy real y peligrosa en la sociedad americana. Esta investigación examinó las experiencias y percepciones de un campus universitario americano típico de estudiantes musulmanas con velo en las secuelas de los más recientes ataques terroristas. Los resultados demostraron que las estudiantes perciben la comunidad del campus como tolerante y acogedora. Por otro lado, las estudiantes reportaron incidentes fuera del recinto, que hablan de la ignorancia y la intolerancia de los estudiantes musulmanes. El estudio proporciona centros de enseñanza superior con conocimientos sobre la forma de aumentar la conciencia cultural del campus para corregir estereotipos y hacer que los estudiantes musulmanes se sienten bienvenidos en sus comunidades. Las autoras esperan crear conciencia entre los estudiantes y miembros de la comunidad; lo que ayuda a desenmascarar los estereotipos, y la creación de un campus seguro y diverso para todos los estudiantes. Los educadores y los líderes universitarios pueden utilizar este conocimiento para luchar contra los estereotipos y prejuicios, para que el campus sea un entorno más seguro y acogedor para todos los estudiantes.

Palabras clave: islamofobia, universidad americana, estudiantes musulmanas 
W

hen the world is compelled to coin a new term to take account of increasingly widespread bigotry that is a sad and troubling development. Such is the case with Islamophobia. (General Kofi Annan, 2004, as quoted by Bleick, 2011, p. 1582).

Having perspective is not something one is born with, rather it is a view or a position acquired through experiences (Beshir, 2007). Unfortunately, most American people's perspectives of Islam and Muslims have been formed through media coverage; particularly in the aftermath of the September 11 and other subsequent terrorist attacks. In many cases, the media, along with policy makers, fail to emphasize that these heinous assaults do not represent Islam or the 1.6 billion Muslims, but instead very small and misguided groups. By doing so, they are labeling Islam, at its core, as violent and intolerant; thus casting blame on all Muslims. Additionally, some politicians have capitalized on this issue by fueling fear and sentiments against Muslims; resulting in Islamophobia. Today, particularly after the France, St. Bernardino, and Belgium attacks, Muslims have to defend themselves and their religion against such associations. Veiled female Muslims in particular, being easier to identify, have become more vulnerable to such bigotry.

\section{Islamophobia}

Contrary to common belief, Islamophobia is not a new phenomenon (Allen, 2007, 2010; Bleich, 2011; GhaneaBassiri, 2013). In fact, suspicion of Islam and Muslims goes back to the early days of the Enlightenment period (GhaneaBassiri, 2013). Chris Allen, a British scholar on Islamophobia, stated, " . . . contemporary Islamophobia is a mere "re-emergence" of a historical anti-Muslim, anti-Islamic phenomenon: a continuum that stretches from before the Crusades to the present day and no doubt in the future" (Allen, 2010, p. 33).

Though the origination of the term Islamophobia as neologism/concept remains contested, inarguably, the 1997 Runnymede Trust report, Islamophobia: a Challenge for Us All was the first to draw attention to the increasingly anti-Islam and anti-Muslim sentiments in its current form (Allen, 2010, 2007; Bleich, 2011). According to The Runnymede report Islamophobia is ". . . the shorthand way of referring to the dread or hatred of 
Islam-and, therefore, to fear or dislike of all or most Muslims" (Allen, 2007, p. 6). The report reinforced the role of the media in the transmission of antiIslam and anti-Muslims sentiments, and concluded that Islamophobic discourse has become " . . part of the everyday life in modern Britain." The Runnymede's definition of Islamophobia did not stop at anti-Muslim attitudes or feelings, rather it extended it to include " . . . the exclusion of Muslims from mainstream political and social affairs" (Runnymede Trust Report 1997, p.4).

The Runnymede characterized Islamophobia according to two sets of views about Islam: "closed views" and "open views." Islamophobia is manifested in the "closed views" mindset of Islam as: "monolithic, barbaric, and unresponsive to new realities"; "separate and other;" "inferior to the West," "violent and supportive of terrorism," "a political ideology." Therefore the "... exclusion of Muslims from the mainstream society and anti-Muslim sentiments should be viewed as natural," and no value should be given to any criticisms of the West that is made by Islam (Runnymede Trust Report Summary, 1997, p.2). This sentiment is particularly familiar to Muslims of the Middle East who were occupied by France and Britain in the early Twentieth Century. During their occupation, French and British forces limited natives' access to education and imposed their languages on those few who were afforded education as the main language arguing that Arabic is not a language for logic and reason. They contended that Muslim cultures and traditions impede the progress and development of the region (Sbaiti, 2010).

The threat of Islam, thus an aversion to Muslims in America, is also not a new phenomenon as it goes back to the early days of the forefathers (Gottschalk, \& Greenberg, 2013). Considering the British influence on its American colonies, American views of Islam were parallel to those of the British. The religion of Islam and American Muslims were considered inferior, anti-American, anti-modern, and throughout the American history Muslims remained the "outsiders" or "the others" regardless of their assimilation into and contributions to American society. Yet, these sentiments remained in abeyance and did not embody the mainstream discourse until 2001 (GhaneaBassiri, 2013). The attacks of September 11, and the subsequent "war on terrorism," have brought Islamophobia to the forefront; thereby triggering an unprecedented, new outward wave of Anti- 
Islam and Anti-Muslim feelings that have marked Islamophobia as the new contemporary American reality. In their 2008 book, Making Muslims the Enemy, Gottschalk and Greenberg described Islamophobia as "[A] social anxiety toward Islam and Muslim cultures that is largely unexamined by, yet deeply ingrained in, Americans" (p.5). They argued, unlike other types of phobias, Islamophobia resulted "from distant social experiences that mainstream American culture has perpetuated in popular memory" (p.5). As a result some misconceptions or stereotypes were associated with Islam and Muslims such as "a violent religion", "the fanatic Muslim man", and "the oppressed Muslim woman” (Gottschalk, \& Greenberg, 2013).

\section{Islamophobia and Women}

There has been an abundance of literature that documented the many aspects of the lives of Muslim women. Much of which has centered on the veils worn by Muslim women and their status under Islamic religion and throughout the Islamic world. The majority of this literature presented the authors' point of views and failed to consider the perspectives of Muslim women. The September $11^{\text {th }}$ attack and the subsequent "war on terrorism" have brought unprecedented public attention to Muslims in the United States. Thus, Islam, Islamophobia, American Muslims, and veiled women have become prominent subjects in America's mainstream news coverage and conversations. This has given rise to Islamophobic attacks; in particular, against Muslim women donning the hijab.

Muslim women and their presumed plight under Islamic religion occupy a cornerstone in the anti-Islam and anti-Muslim sentiments. The most common themes of this aspect are: the oppression and subjugation of the Muslim woman due to her veiling, and her dire need for liberation (Ahmed, 1992; Abu-Lughod, 2002; Gottschalk, \& Greenberg, 2008; Haddad, 2007; Khan, 2002). The veil (also known as hijab, niqab, headscarf, and burqa), being the most obvious "outward" indicator of Muslim women's identity, has become the symbol for their lack of agency, backwardness, victimization, and a clear demonstration of oppression under Islam. It is also regarded as anti-modern; thus anti-American and antagonistic to the American way of life. Muslim women (who don the hijab) have become direct targets of hate crimes, discrimination in employment and education, 
and harassment and bigotry in public places. Juliane Hammer (2013) argued

Muslim women occupy center stage in Islamophobic discourse in two distinct and contradicting ways. As objects of hate crimes and discrimination, Muslim women have Islamophobia mapped onto them directly and as representations of Muslims in American society; as objects of anti-Islamic discourse Muslim women are represented as victims of their religion, culture and Muslim men, and thus in need of saving, liberation, and intervention (p. 110).

In the same context, she also stated that Muslim women usually "are not spoken to, but rather spoken about" (p.116). In Hammer's opinion, it is as if they are objects incapable of thinking or defending themselves, and in dire need of liberation. She believes it is because of their obvious Islamic identity that they have become a direct target for increasing hate crimes and violence.

On the other hand, Yvonne Yazbeck Haddad (2007), a professor at Georgetown University, stated that donning the hijab after September 11 has given second-generation American Muslim women the assurance of their freedom of speech and religion, and has become "a symbol for authenticity and pride" (Haddad, 2007, p. 254). Sally Campbell Galman (2013), an associate professor at the University of Massachusetts-Amherst, analyzed the experiences of three American females converting to Islam, Orthodox Judaism, and Orthodox Christianity. Interestingly enough, Galman (2013), borrowing Kenji Yoshino's 2006 interpretation of covering, argued that covering (wearing the veil or other distinguishing religious garments), as a religious requirement is "paradoxically an act of uncovering." When covering, females are uncovering their religious identity and refusing to conform. In the case of the Muslim participant, the hijab was a choice, and it was not about covering the hair rather it was about "simply to be visible' ( $p$. 429). Galman concluded for her participants that the act to uncover "was also an act of resistance to the so-called mainstream and its underlying assumption" (p.436). She went on to say " . . . against this backdrop that veiled women became the most frequent targets of anti-Muslim harassment and hate crimes as, 'uncovered,' they are the most visible" (p.436).

While the hijab is considered a symbol of oppression, victimization, and 
"otherness", according to the Western mainstream, it has completely different functions and understandings to those who don it. In Redefining the Hijab: American Muslim Women's Standpoints on Veiling, Rachel Anderson Droogsma (2007) stated researchers on Muslim women veiling rarely investigated the functions of the hijab from the veiled women perspectives and own experiences. Thus, researchers end up 'ascribing' meaning rather 'describing' the true functions of the veil in the lives of Muslim women. Existing research tends to focus on Arab and Muslim female experiences outside the United States. However, Droogsma (2007) examined the experiences of thirteen veiled American Muslim women, and the functions of the hijab throughout their daily lives in the United States. Contrary to common perception, the study found American Muslim women are donning the hijab for different reasons. The first of which is to define their identity as being Muslim or non-Muslim. To these females covering is to show and appreciate their association with their religion. It becomes a source of pride and a way to defy stereotypes as "they purposefully contradict these discourses in order to present an alternative understanding of women who veil to the persons who meet them" (p. 303).

\section{Theoretical Framework}

Kalkan, Lyman, and Uslaner (2009) explained American Islamophobic sentiments using the Social Identity theory. According to this theory, people tend to divide their society into social groups of "them" and "us" depending on their resemblance or lack thereof to themselves; thus they cognitively trust those who are similar to them and label them as "us" and distrust those who look different from them and are labeled as "them." Kalkan, et al. (2009) argued "Muslims' religious beliefs and practices, cultural orientations and ethnicities have long made them different in key ways from the JudeoChristian mainstream" (p. 847). Thus, Muslims were and continue to be seen as "others" "out groups" and "outsiders." According to their research, Kalkan, et al. found that, unlike other "outgroups" in American history, Muslims carry an extra burden because they fall within two different categories; racial and religious.

The authors of this study contend that veiled Muslim women tend to shoulder most of the brunt of Islamophobia because of their distinct 
appearance and the perception that they are oppressed. They are easily identified as other or different and therefore exposed to more harassment from westerners due to ignorance or lack of acceptance of differences. The newspapers are replete with harassment and aggression incidents against Muslim veiled women after each terrorist attack. For example, right-wing conservatives in a peace rally in Belgium signaled Muslim women out after the most recent terrorists attack (Broomfield, 2016).

\section{The Study}

There have been several incidents of Islamophobic acts reported against Islam and Muslim students across American campuses. Some examples are students shouting "ISIS" at them or grapping their headscarves as they walk on campus (Thomas, 2015). This study is seeking to explore experiences of Muslim Female students' at a typical university campus, and how they have navigated their presence in the community. Since their lives and daily activities are not limited to on-campus activities, the study also examined their experiences off-campus. It explored the effects Islamophobia has had on the everyday lives of Muslim Female Students at a mid-southern university, and what kind of challenges and backlashes, (if any), do Muslim Female students experience at the university? Have they been subjected to any kind of discrimination (physical or verbal) due to being Muslim? Have these challenges, if any, changed their mind about continuing their education at the university? Have they considered changing their appearance (not covering their heads) to conceal their Islamic faith? And do they feel threatened when walking on or off campus?

\section{Methodology}

This is a qualitative study aimed at exploring the challenges Muslim female students experience at a mid-southern university; due to the rise of Islamophobia in the aftermath of the most recent terrorist attacks. Specifically, it examined the kind of challenges or backlashes, if any, that Muslim female students have experienced. The first author conducted fourteen semi-structured, face-to-face interviews with veiled Muslim female students during the fall of 2015 and spring of 2016. The research inclusion 


\section{Mrayan \& Saleh-Not Without Their Hijab}

criteria were veiled Muslim female students enrolled at the university or the Center for English as a Second Language (ESL) for at least one semester prior to participation in the study. The interviews were conducted on and off-campus, and were transcribed, coded, and analyzed. Participants were asked a set of questions pertaining to their experiences as veiled Muslim students. The majority of the participants had attended other US colleges prior to coming to this university. The participants were instructed to only talk about their experiences at the campus where the study is carried out.

The first author supplemented the data with follow-up phone calls and text messages to clarify or touch on issues that were overlooked during the interviews when needed. Snowballing and Convenience samplings were used for recruitments. The majority of the respondent spoke Arabic as their first language and English, in varying degrees, as their second or third language. Interviews were conducted in English and Arabic depending on the participants' command of the English language. In many cases, the interviewer asked the questions in English and Arabic respectively to eliminate any chances of misunderstanding, and to provide the participants with a fair chance to comfortably present their experiences in the best form. Also, participants had the choice of answering in English or Arabic depending on their command of the language. Ten participants were graduate students, two undergraduates, and two were enrolled at the ESL program. Three of the participants were graduate assistants. Thirteen of the participants were classified as international students studying abroad. Six of these were married with at least one child. All participants lived off campus, but one.

Throughout this research, the authors used the terms hijab, headscarf, and veil interchangeably for referring to the customary head cover Muslim females don to cover their hair and neck. Women who don the hijab are referred to as hijabi. Also, the hijab donned by the majority of participants was a headscarf that covered the hair, neck, and chest and should not be confused with the Burqa or the full face veil used in Iran, Afghanistan, and Saudi Arabia.

\section{Findings}

Analysis of the data revealed four themes that categorize the participants' 
experiences as Muslim female students: on-campus experiences, off-campus experiences, wearing the hijab, and communications and interfaith dialogues.

\section{On-Campus Experience}

The majority of participants described their experience on campus as fair, unbiased, accommodating, and of a nondiscriminatory nature. The participants have not experienced any serious challenges that hindered or compromised their education or made them reconsider their decision of attending this university. There were no signs of agitations or stress shown by participants during discussions of their experiences. Two participants talked of minor challenges due to culture differences, but they were not of an Islamophobic nature. The majority of participants described their experiences on campus as being nice, friendly, and accommodating. One student described her experience, "In my department, I feel they are very nice and friendly. Very respectful in their dealings with us [Muslim students]." Another participant said, "Nobody treated me bad." A graduate assistant student stated, "My supervisor is very nice and she doesn't discriminate," and went on to say that as far as the supervisor was concerned, "my religion was not of an issue at all." None of the participants reported being questioned about, harassed, or confronted in the aftermath of any terrorist attack, and none had to explain or justify the attacks.

Praying at set periods of time is a fundamental part of practicing Muslims' lives and plays a significant part in their daily routines. For some, the availability of a private place to pray made a positive impact on their experience on campus. One respondent said, "There is something that really impressed me about the dean of my department. Once I went to the administrator and told her that I needed a private place or a corner because I wanted to pray. She said, "the only thing we have is a hall, and the dean has the keys." After she had talked to the dean, he made the room available for her and posted a "don't disturb" sign on the door to allow her to pray. She stated, "Frankly, it impressed me....since then I said this is it. These people are nice." Another student said, "Once during lab, one Muslim student asked to be excused for few minutes to pray and the faculty "was ok with it." A graduate student said she feels at ease on campus and does not hesitate to 


\section{Mrayan \& Saleh - Not Without Their Hijab}

pray anywhere and whenever she needs to on campus. Yet others said that not having a place to pray on campus is inconvenient; causing some students to commute back and forth during their school hours.

Still, five separate negative incidents were reported by the participants to had taken place on campus. During two of the incidents, participants were directly ridiculed or taunted because of their faith. In one incident a male student tried to mock and provoke the respondent by blocking her way and preventing her from going forward while his friends stood nearby watching. As she screamed at him not to "touch her," he backed away nonchalantly to join his friends. Another undergraduate student felt one of her previous instructors was very unsupportive. She said that once after inquiring about her grades, he was very rude, dismissive, and said "she was wasting his time." Two other incidents that reported (one of which involved praying on campus), but the nature of these incidents was not clear. Although these participants seemed bothered and agitated with the incidents they indicated the incidents could have had different interpretations or meanings.

None of the participants were physically or verbally assaulted, none were forced or asked to remove the hijab, and only two students experienced stigmatizing stares on campus. The respondents reported they were subjected to stares from the students.

When I am in the lab and there are undergraduate students, I feel they are staring at me. Their looks were strange, but nobody said anything demeaning or anything. But maybe they are not accepting the idea or they haven't seen Muslim students before.

On the other hand, the majority of participants felt they were welcomed and safe on campus. As one student summarized, "I have never felt scared on campus, and nobody looked at me with animosity. I believe they are used to seeing Muslim students with hijab on campus".

All felt their presence was welcomed among faculty, staff, and students. The majority agreed the faculty was the most welcoming and supportive of Muslim female students. All participants contributed this finding to the faculty's level of education, as well as their experiences of dealing with Muslim students. One student said the faculty works directly with Muslims, so they have formed a better idea about Muslims. "They met Muslims, they 
knew Islam and probably they knew more about Islam and Muslim students." Another participant said,

Faculty [are] more understanding. I think some of them lived with Muslims before so they know what we are about... and I actually feel much safer with them than with students -not to say that I don't feel safe with students- because I do. But, I don't know, with the faculty I feel they know me, they understand me.

\section{Off-Campus Experiences:}

Most of the participants felt, for the most part, welcomed in the community, but not by everybody or everywhere. Thus, "going to town" was not as easy or uneventful as going to college for the participants. While only three students felt they were directly harassed or targeted on campus because of their faith, the majority of participants reported at least one incident or had experienced at least one off-campus discriminatory act. Few members of the community exhibited "closed views" of Muslims and made sure to let it be known with angry shouts from drivers and passengers, stigmatizing stares and angry looks from passersby and commuters, and other sporadic incidents of discrimination. With the hijab being a universal symbol and identifier of Muslim women, these students were easily identified. Their acceptance in the community (or lack thereof) became contingent upon the onlooker's own perceptions of Islam. Some participants did feel they were welcomed in the community, and that people were "very, very, nice" and "very understanding and welcoming of Muslims." While at the same time there were other people who couldn't see beyond their own bigotry; so much so that an act of kindness was rejected point blank because it came from a young Muslim female student.

Those who did manifest "closed views" of Islam sought multiple ways of exhibiting their sentiments against Muslim females. Some were "mean and hateful," while others were not so confrontational. A graduate student reported being confronted at a gas station by an angry customer. The student revealed that as soon as she passed the customer, he shouted "what the f... are these Muslims doing here? We should get rid of them." Afterward, he went to the cashier to complain that "he wanted to get rid of me and all the 


\section{Mrayan \& Saleh - Not Without Their Hijab}

Muslims." Upon hearing him, the cashier and the participant's friend made it clear to him that they did not share his sentiments and lack of empathy for Muslims. In another unfortunate incident, a participant said she and a friend were walking around the neighborhood and were harassed by a young male that groped her friend from the back. She stated that after the perpetrator had groped her, he stood there laughing and did not even try to hide or run away indicating that he thought very little of them. An ESL student reported that when visiting an assisted living home, as part of her ESL curriculum, one elderly male resident refused to talk or acknowledge her. Not understanding his action at the beginning, the student reported that she came closer to him and tried to offer him some of the food the students brought with them. Upon which the elderly man raised his hand and turned his face away indicating that he did not want to see her. After the second incident of this nature, the ESL Center issued an apology to the student and excused her from going to the nursing home throughout their remaining visits.

Others were not as confrontational. They sought to convey their sentiments by talking bad about Muslims in the presence of Muslim females. One participant reported while shopping at the Mall, a shopper passed by her and called her a "terrorist." As soon as she turned around and looked at him, he said "I am not talking to you," but the participant stated, "it was clear that he was addressing me and he intended for me to hear it." Another participant said that while riding on the bus, the bus driver spoke badly of Muslims and made derogatory remarks about Muslims' and their lack of etiquette. He did not talk to her directly, but the driver knew that she was sitting close enough to hear the conversation. Another student said,

Sometimes, I feel they are not friendly. When I am at the cash register checking out, her [the cashier] way of talking or dealing with me is different or let's say not as friendly as she was with the customer who was ahead of me. But sometimes I don't care.

While the general consensus among participants regarding stigmatizing stares on campus was "never," "seldom," or "rarely," the majority of participants experienced this kind of looks from community members, particularly from senior citizens. One student said, "Nobody said anything bad or tried to bother me. It is very nice here, but the stares. I don't 
understand why".

Another student said:

Nobody bothers me, but I get lots of stares....I noticed this at public places. I haven't experienced this on campus, only in public places. When my husband and I go there, especially when my husband and I are walking together, they stare at you. More than one person. Not one or two or three. My husband sometimes says 'look, look, look at them"”. "It bothers me. Sometimes I pretend I don't see them, and sometimes I stare back at them....Mostly from the older ones.

When asked if she encounters these stares very often, she said, "a lot. A lot. Just yesterday we were at Walmart, and some people were staring. I think it is the way I wear my hijab." The majority of the participants wore headscarves that cover their heads and necks. This participant wore a long scarf that covers her head and well as her chest.

Another participant said,

In the beginning, I thought maybe because they are not used to seeing Muslim females donning the hijab. I see it here on campus, but I see it more off-campus. . . Sometimes I feel there is something in their looks especially after terrorist attacks; I feel the looks increase."

When asked what they make of these stares and angry looks, a few participants said it is as if saying "Why are you here? What brought you here?" Others said these stares are meant to be "condescending and degrading."

Over fifty percent of respondents reported they had faced angry shouts and screams from drivers and passengers. The frequency of these types of incidents varied from one to another. Some reported they witnessed it only once, while others said, "Many times, somebody sticks his head out [of the car] and yells," "It happens all the times, on the streets. I don't hear their exact words, but they scream." "You can tell they are mad." One participant revealed that she had faced this kind of attack only once, but it was very offensive. 
Feeling threatened and unsafe off campus was a common thread among participants' responses. Ninety-two percent (13 participants) live off campus and commute back and forth to school. They felt scared and threatened when walking off campus, "Not at all on campus. Never. Only on the streets." Two students have contributed their fears to the media coverage of presidential candidates' anti-Islam rhetoric.

Because of what took place and what's being said in the news. Because I don't want to be attacked. Now, I feel Trump is telling people if you don't like them, it is ok to take a stand against them, and do what you please because we don't want them here. So this might encourage anybody who is psycho or disturb[ed] or hateful, it is ok to attack me because my identity as a Muslim is obvious.

She Added,

Because of what I hear and see in the news, as soon as I walk on the street I get scared, expecting somebody to run over me with his car, do something to me... Imagine, I wasn't scared at all at the other state... I wasn't afraid at all, but here, as soon as I came here and I started hearing the news...I began to feel threatened.... But not in the university. Never. . .Yes, I do.....especially with the presidential elections and all that, what's being said about Muslims and all of that, so I feel more threatened now than before.

\section{Wearing the Hijab}

Participants said most inquiries they received about Islam were about the hijab. Students, community members, and children were curious about the rules and regulations that govern wearing the hijab and when and where the hijab can be taken off. All inquiries were friendly and not perceived to be demeaning or hurtful. A few participants were asked to remove their hijab out of curiosity and some participants obliged (to females and children). All participants said they did not mind being asked about Islam or the hijab. Others saw this as a way to clear common misunderstandings about Islam and the hijab, in particular. One respondent recalled an encounter during a 
school exhibition with a non-Muslim international student, who asked the veiled student why she wore the Hijab and if it made her feel strange walking among people. An acquaintance of the respondent happened to hear the conversation and was not pleased with the tone of the questioner. She told the participant that she did not have to answer his questions, as he had no right to ask personal questions in such a manner. However, the participant explained she would prefer people ask questions and be informed about the hijab and Islam, rather than making erroneous assumptions and adhering to stereotypes. This participant was not alone regarding her approach of answering questions about Islam and the hijab. All participants said they welcomed any kind of questions about Islam; as one participant put it "with arms wide open."

None of the participants have thought about or even considered taking their hijab off. To some participants, the mere notion of this idea seemed rather ridiculous. Single as well as married students asserted they have never considered taking off their hijab. "I chose the hijab, nobody imposed it on me. If things get very bad, I will go back home." Another student said, "I wore the hijab because I wanted to, nobody imposed [the hijab] on me, and nothing is going to change my mind." One student commented,

I didn't change my mind because I knew before I came here that I will face these things. Yeah, previous students talked about these things and situations much worse than these. People ask me about Islam before they even ask about my name or anything.

With the exception of one student, none of the participants considered disguising or camouflaging her Islamic identity by toning down her Islamic appearance.

During a recent active shooter incident on campus, before the identity and the intention of the shooter was revealed to be non-Muslim, one participant admitted she was very scared. She sheepishly confessed she thought about removing her hijab so as to blend in with everyone just in case the shooter might target her if a confrontation took place. However, she quickly reasoned with herself, "Why are you doing that. This is who you are, so just stick to what you have. If it happens that he shoots at you, then it just happened." Another student was asked during a job interview if she were 
hired would she consider changing her appearance by wearing a hat instead of hijab. As a result, the respondent decided not to go back and to look for employment someplace where her hijab wouldn't be an issue.

Many of the participants said if Islamophobic rhetoric intensified to the point they felt their lives would be in danger, then they would rather leave the country than remove their hijabs. Only one participant said she had been considering toning down her appearance by wearing a hat instead of a hijab since she walks at night by herself from school to her place of residence. She also said she would not consider uncovering her hair. One said with absolute resolution, "We are going to stick with the hijab."

\section{Communication and Interfaith Dialogue}

The findings revealed a lack of interaction and connection between female Muslim students and American students. One participant said she was warned earlier about the lack of interactions:

It is very hard to make friends with American [students], it is easier to form friendships with internationals, and that's what I have observed. If you ask them [American students] questions, they respond with apparent difficulty....more than once, I tried to mingle with the students, but it is difficult.

A few participants spoke about the lack of interfaith dialogue on campus. Very few were approached by non-Muslim students. "Very little questions, people are not interested." "They don't care because nobody tries to talk to you or ask you questions or anything. They don't care. They ignore you."

On the other hand, the majority of participants said they would welcome and encourage any inquiries or questions about Islam because they feel this could open many doors for constructive dialogues. This in turn could help correct misunderstandings; thereby maybe eliminating stereotyping and Islamophobic sentiments. "Yes, because I want to communicate to them the Islam I know not the Islam they know. They know Islam as bombs, killing people, and terrorist." One student related,

Once in the gym, a lady.... stopped me and asked 'is it true what we 
hear about you? This is the first time I meet a Muslim female face-toface, and I want to ask" So I said to her, you hear wrong things about us, and we too hear bad things about you. The media is all wrong." Then she said "I feel you [Muslims] are friendly, but I am afraid of you [Muslims].

When asked if they felt that they have to apologize in the aftermath of any terrorist attack, all participants said "no". All were of the opinion these attacks did not and could not represent Islam in any way. One student said, "If Muslims apologize for those kinds of attacks it is as if Muslims are saying that this is Islam and we apologize for it when in reality it is not." Another stated,

I don't feel that I have to apologize, but I should explain. If given the opportunity to explain to them this is not a representation of Islam or Muslims.... I know my religion, and my religion does not condone violence.

All participants wanted to be clear that although they feel there are individuals within the community who are prejudiced and would not hesitate to exhibit their bigotry and lack of tolerance, this does not speak of the community as a whole. They all insisted this group of people does not represent the entire community. They commented that the majority of the people they encounter are "very" friendly and understanding people, who are willing to "at least hear you or give you a chance." In the same time, there are some who are very unfriendly. A graduate student said, "I work on and off campus, and I have not encountered any looks or anything...but yes, I heard my friends say that they are facing weird and unfriendly looks," Another graduate student summarized her experience off campus as " . . f for the majority part I would say yes, I would say probably about 80-90 percent [of the time] I feel welcomed".

\section{Discussion and Implications}

Edward Said (1981), the author of Orientalism, cautioned " . . . there has been a gross simplification of 'Islam,' so that numerous manipulative aims 


\section{Mrayan \& Saleh - Not Without Their Hijab}

can be realized, from stirring up of a new cold war, to the instigation of racial antipathy, to mobilization for a possible invasion, to the continued denigration of Muslims and Arabs" (Said, 1981, p. xviii).

Equity and inclusion are the driving forces behind most universities' diversity goals and mission. Shabana (2014), citing Abelmann (2009), stated " . . . in the liberal narrative of college, there is inherent claim-a promise, a 'university imaginary,' an individualistic, universal dream of full humanity that is accessible to all regardless of their particular characteristics" (p.31). However, today it is neither a secret nor a surprise that the presence of Muslim students, particularly veiled females, on American campuses is associated with a distinctive (and in most cases) negative stigma (Shabana, 2014).

Bleich's (2011) analysis of existing Islamophobia definitions argues that Islamophobia is " . . . indiscriminate negative attitudes or emotions directed at Islam or Muslims" (p.1583). This study demonstrated through incidents carried out against participants that these acts are indeed "indiscriminate." They have no logic or rational other than bigotry and intolerance for anything outside the mainstream. These incidents were triggered by the recent terrorist attacks and presidential election campaigns and targeted veiled women because they are easily identified as Muslims.

Overall the participants felt their experience as veiled Muslim students on campus is fair and pleasant. All agreed that little signs of any Islamophobic sentiments have been exhibited on campus, and there were no major challenges or discrimination that would make them reconsider or change their mind about attending the university. A few participants spoke of minor issues because of cultural difference or some students' immaturity, but none was of an Islamophobic nature. However, as mentioned earlier, there were a few sporadic incidents on campus where the students did feel they were targeted because of who they were.

Also, the findings revealed ambivalence in the acceptance of Muslim females within the community. Their acceptance in the community or lack thereof varied according to each community member's understanding and perception of Islam. For the most part, the respondents felt welcomed in the community. Yet, their presence off-campus; in the mall, shopping centers, restaurants, and streets has been frowned upon and has triggered certain negative behaviors from a few members of the community. Examples of 
these behaviors included physical confrontations, angry looks, shouts from onlookers, being called terrorists, being asked to leave the country, and being told to go back home. All participants stated they felt threatened when walking off campus, particularly after the recent attacks and presidential election campaigns.

While Islamophobes are trying to show that donning the hijab is a sign of oppression or victimhood, the authors argue, based on the findings, it is a sign of fearlessness and persistence. Participants showed a sense of agency and steadfastness in facing stereotypes and bigotry. By wearing the most visible marker of the Islamic faith, the hijab, in non-Muslim countries when pressure is mounting to do otherwise, they are demonstrating brave acts of perseverance and empowerment. These students have "uncovered" their Islamic identity to represent Islam and defy stereotypes of oppression and lack of agency by donning the hijab. Thirteen out of the fourteen participants are classified as international students studying abroad, and nine are single and living on their own. They have had ample opportunities to tone down their appearances (their Islamic identity) either by wearing a hat or taking off the hijab entirely, yet they all chose not to. They affirmed that as the hijab revealed their Islamic identity, they hoped to serve as representatives of Islam in the West. "I insist more in wearing my hijab in USA because it presents part of my identity as a Muslim woman", "to contradict the American concept" of the oppressed Muslim women, and to be a role model of "Muslims as nonviolent; but peace seeking people." Kenji Yoshino (2006) wrote "In the American dream, assimilation helps us become not just Americans, but the kind of Americans we seek to be. Just conform, the dream whispers, and you will be the respected, protected, accepted" (p.20). These students have clearly understood their marginality in society and they used their roles as source of resistance to affirm their Islamic identity and defy Islamophobia.

The authors argue the act of covering and thus "uncovering" (Galman 2013; Yoshino 2006) of their Muslim identity is not a lack of agency nor is it a sign of oppression. All fourteen participants stated they were easily identified as Muslims by non-Muslims and were aware of the stigma associated with Islam and Muslim women. Yet, they insisted on the hijab hoping to contradict stereotypes, and serve as "representatives of Islam"; as they know Islam and not what Islam is perceived to be. 


\section{Mrayan \& Saleh - Not Without Their Hijab}

This study also showed the veiling experience as a dynamic and complicated experience; far from being "static and unified." The participants hope to use the veil to bring about social changes; eliminate racism and stereotyping, and freedom from societal bonds and restrictions. The findings reinforce earlier contentions by Abu Lughod (2002) and Hammer (2013).

The results of this study supported earlier findings of People for the American Way, the Center for American Progress, the Southern Poverty Law Center and Fear Inc. Their reports found that anti-Muslim sentiments were aimed at creating fear and hate among Americans and was "manufactured by-products" by a small but influential group of the rightwing conservatives (Ernst, 2013). This group is spending millions of dollars to fund anti-Islam and anti-Muslim campaigns. So far they have only succeeded in creating small pockets of bigotry and hate throughout America's community, but in no way does it represent the entire American society or its values.

The society, especially higher education, must take it upon itself to educate its communities on the facts and the dangers of Islamophobia not only for Muslims but on their safety and stability as well. We must also increase awareness among politicians and community leaders not to use Islamophobia as a tool to garner support for their political campaigns. Higher education institutes should create an inviting environment for Muslim students. They should develop activities that involve all students outside the classroom that integrate students and encourage them to exchange ideas and discuss cultures and traditions. The university should also create opportunities to engage society members with Muslim students on campus and provide talks and seminars that serve to dispel misconceptions and fears of other cultures.

The contention of the authors is that veiled female students are easily identified as Muslim and are more susceptible to prejudices, discrimination, and having to confront stereotyping. The authors hope the knowledge gained from this research will shed some light into the experiences of Muslim female students at a typical American campus. Islamophobia is intolerance and racism. Muslim students have the right to be who they are and feel as safe as any other students on- and- off-campus. By shedding light on this issue, the authors wish to bring attention to any prejudices and discriminations existing on the campus and the surrounding community. 
RISE - International Journal of Sociology of Education, 5(2) 265

\section{References}

Abu-Lughod, L. (2002). Do Muslim women really need saving? Anthropological reflections on cultural relativism and its others. American Anthropologist, 104(3), 783-790.

Ahmed, L. (1992). Women and Gender in Islam: Historical Roots of a Modern Debate. New Haven: Yale University Press.

Allen, C. (2010). Islamophobia. Burlington VT: Ashgate Publishing Company

Allen C. (2007). The first decade of Islamophobia: 10 years of the Runnymede Trust report "Islamophobia: a challenge for us all", 1-29.

Beshir, S. (2007). A Light at the End of the Tunnel: The Stories of Muslim Teens. Beltsville, MD: Amana Publication

Bleick, E. (2011). What is Islamophobia and how much is there? Theorizing and measuring and emerging comparative concept. American Behavioral Scientist, 55(2), 1581-1600. doi:10.1177/0002764211409387 Broomfield, M. (2016, March 28). Far-right protesters in Brussels confronted and intimated Muslim women on a Peace March. The Independent, http://www.independent.co.uk/news/world/europe/400fascist-protesters-in-brussels-square-confronted-and-intimidatedmuslim-women-a6956196.html

Droogsma, R. A. (2007). Redefining hijab: American Muslim women's standpoint on veiling. Journal of Applied Communication Research, 35(3), 294-319. doi:10.1080/00909880701434299

Galman, S. C. (2013). Un/covering: Female religious converts learning the problems and pragmatics of physical observance in the secular world. Anthropology \& Education Quarterly, 44(4), 423-441. doi:10.1111/aeq. 12040

GhaneaBassiri, K. (2013). Islamophobia and American history: Religious stereotyping and out-grouping of Muslims in the United States. In C. W. Ernst (Ed.), Islamophobia in America: The anatomy of intolerance (pp. 53-74). New York: Palgrave MacMillan

Gottschalk, P., \& Greenberg, G. (2013). Common heritage, uncommon fear: Islamophobia in the United States and British India, 1687-1947. In 
C. W. Ernst (Ed.), Islamophobia in America: The anatomy of intolerance (pp. 21-51). New York: Palgrave MacMillan.

Gottschalk, P. \& Greenberg, G. (2008). Islamophobia: Making Muslims the Enemy. Lanham: MD Rowman \& Littlefield Publishers.

Haddad, Y.Y. (2007). The post-9/11 Hijab as Icon* Sociology of Religion, 68(3), 253-267.

Haddad, Y.Y, Smith, J.I. \& Moore, K.M. (2006). Muslim Women in America: the Challenge of Islamic Identity Today. Oxford: University Press.

Hammer, J. (3013). Center stage: Gendered Islamophobia and Muslim women. In C. W. Ernst (Ed.), Islamophobia in America: The anatomy of intolerance (pp. 107-144). New York: Palgrave MacMillan

Hoodfar, H. (1993). The veil in their minds and on our heads: The persistence of colonial images of Muslim women. Resources for Feminist Research, 22(3/4), 5-18.

Kalkan, K., Layman, G., Uslaner, E. (2009). "Bands of Others? Attitudes toward Muslims in contemporary American society. Journal of Politics, 71, 1-16. doi:10.1017/S0022381609090756

Khan, S. (2002). Aversion and Desire: Negotiating Muslim Female Identity in the Diaspora. Women Press. Ontario, Ca.

Said, E. (1981). Covering Islam. New York: Pantheon.

Sbaiti N, (2010). If the devil taught French: Strategies of language and learning in French mandate Beirut. In Osama Abi Mershed, Trajectories of education in the Arab World. (pp. 59-83) NY: Routledge.

Shabana, M. (2014). Muslim American Women on Campus: Undergraduates Social Life and Identity. Chapel Hill: The University of North Carolina Press.

People For the American Way (PFAW), The Right Wing Playbook on AntiMuslim Extremism.

The Runnymede Trust Report Summary (1997). Islamophobia: A challenge for us all. London: Runnymede Trust.

Thomas, D. (2015, December 7). What it's like to be a Muslim woman after a terrorist attack. The Los Angeles Times, http://www.latimes.com/local/la-me-ln-women-anti-muslim-harassment20151206-story.html 
RISE - International Journal of Sociology of Education, 5(2) 267

Yoshino, K. (2006). Covering: the Hidden Assault on our Civil Rights. New York: Random House.

Suhair A Mrayan is Doctoral student of Educational Leadership at the Center for Excellence in Education, Arkansas State University.

Amany I Saleh is Professor of Curriculum and Instruction at the Center for Excellence in Education, Arkansas State University

Contact Address: suhair.mrayan@smail.astate.edu 